\title{
A STUDY ON THE RISK-ADJUSTED PERFORMANCE OF MUTUAL FUNDS INDUSTRY IN INDIA
}

\section{Shivangi Agarwal, Nawazish Mirza}

(1) Business Analyst, UBS India (2) S P Jain School of Global Management, Dubai International Academic City

Shivangi Agarwal Business Analyst, UBS India shivangi.mjanı6gfoo8@spjain.org

Article info Paper category: Preliminary paper Received: 23.3.2017. Accepted: 27.4.2017. JEL classification: G10, G11, G23 


\begin{abstract}
Investing through mutual funds has gained interest in recent years as it offers optimal risk adjusted returns to investors. The Indian market is no exception and has witnessed a multifold growth in mutual funds over the years. As of 2016, the Indian market is crowded with over two thousand mutual fund schemes, each promising higher returns compared to their peers. This comes as a challenge for an ordinary investor to select the best portfolio to invest making it critical to analyse the performance of these funds. While understanding and analysing the historical performance of mutual funds do not guarantee future performance, however, this may give an idea of how the fund is likely to perform in different market conditions. In this research we address multiple research issues. These include measuring the performance of selected mutual schemes on the basis of risk and return and compare the performance of these selected schemes with benchmark index to see whether the scheme is outperforming or underperforming the benchmark. We also rank funds on the basis of performance and suggest strategies to invest in a mutual fund and therefore, our findings have significant relevance for investing public.
\end{abstract}

\title{
Keywords:
}

Mutual Funds, Risk Adjusted Returns, Value at Risk. 


\section{INTRODUCTION}

Investment is very vital to park the surplus fund by an individual for the purpose of earning additional revenue or capital appreciation or both. An investor has to take into consideration various factors while crafting an investment decision. These are: risk associated with the investment, tax benefits, liquidity, and marketability etc. Mutual funds are investment option available to investors through which they can invest in an asset class of their choice such as equity, debt, gold or real estate etc. Investors who may not want to invest directly in financial markets may instead get exposure to the same securities through a mutual fund. Also, mutual funds provide flexibility to liquidate investment position at any point in time.

The concept of mutual fund is that of a portfolio. The money pooled in by a huge number of investors is what makes up a Mutual Fund. This money is then managed by a specialized Fund Manager, who uses his investing management skills to invest it in numerous financial instruments. The investors in turn will own units, which essentially represent the share of the fund based on the invested quantity. The rise in value of the investments along with other profits earned from it is thenceforth passed on to the unit holders in proportion to the number of units owned after charging for applicable expenses, load and taxes. Like other investment alternatives, mutual funds come with a risk as well and the value of mutual funds will change if the value of the investments change, thus making the mutual funds exposed to volatility but to a limited extent. The Mutual Fund industry in India is fairly mature and has witnessed growth as well as structural changes since its inception. By the initiative undertaken by the Government of India(GoI) and the Reserve Bank of India(RBI), the first mutual fund was rolled out by Unit Trust of India(UTI) in 1963. Later, UTI was joined by State Bank of India (SBI) in 1987 to enter the MF industry. Subsequently, the year 1993 proclaimed another time in the MF industry. This was set apart by the setting up of privately owned businesses in the sector. After the Securities and Exchange Board of India (SEBI) Act was passed in 1992, the SEBI Mutual Fund Regulations appeared in 1996. From that point forward, the Mutual store organizations have kept on growing exponentially with the foreign companies entering India, through joint endeavors and acquisitions.

As the business extended, a non-benefit association, the Association of Mutual Funds in India (AMFI), was built up on 1995. Its goal is to advance sound and moral marketing practices in the Indian MF Industry. SEBI has made AMFI affirmation obligatory for each one of those occupied with offering or advertising mutual fund product. The average assets under management (AUM) of Indian mutual funds in 2016 had risen to INR 14.41 trillion ${ }^{1}$ for the first time due to light inflows in equity and short-term debt funds. Gilt and long-term debt funds saw certain retrenchment. Equity funds stood at INR 4.74, trillion and contributed mark-to-market (MTM)

1 Approximate exchange rate is $1 \mathrm{USD}=65 \cdot 4 \mathrm{INR}$ 
profits of above $\eta \%$ in 2016. In the same period, short-term debt funds reached to a high of INR 1.60 trillion while Ultra short-term fund assets rose to INR 1.47 trillion. Liquid fund assets remained at INR 3.42 trillion while Income fund assets contracted to INR 35.81 billion. Finally, Gilt fund assets soared to INR 152.07 billion ${ }^{2}$.

Given this exponential growth in the mutual fund industry, the Indian market is crowded with over two thousand mutual fund schemes, each promising higher returns compared to their peers. This comes as a challenge for an ordinary investor to select the best portfolio to invest making it critical to analyse the performance of these funds. While understanding and analysing the historical performance of mutual funds do not guarantee future performance, however, this may give an idea of how the fund is likely to perform in different market conditions. Furthermore, as funds are diversified, their performance should not be solely based on absolute returns but instead must take into account risk adjusted returns. Therefore, a study on mutual fund industry will have plausible policy implications for the participants. In this research we aim to address multiple research issues. These include measuring the performance of selected mutual schemes on the basis of risk and return and compare the performance of these selected schemes with benchmark index to see whether the scheme is outperforming or underperforming the benchmark. We also aim to rank funds on the basis of performance and suggest strategies to invest in a mutual fund depending upon the objectives of the investors, risk appetite, duration of investment, etc. The rest of the paper is organized as follows. Section II provides a review of literature on mutual funds, Section III discusses data and methodology, Section IV is dedicated for results and Section V will conclude.

\section{LITERATURE REVIEW}

Performance measurement plays an important role for investors when deciding to invest in mutual funds. Since Markowitz (1952), several indicators have been developed to assess fund performance. Traditional indicators are also accompanied by the measures that evaluate conditions such as asset allocation and performance persistence. The rising number of indicators might lead to a more confused performance evaluation as the use of the innumerable indicators can lead to wavering results and varying fund rankings.

Razafitombo (2010) noted that there is ample academic literature on performance measurement, few studies made contrasts between the various measures. The results found in the literature are controversial. If certain studies found no convergence amid funds' rankings obtained with numerous measures (Plantinga and De Groot 2002), others reach unlike conclusions, such as convergence amongst a group of measures, nonetheless with the Sharpe ratio standing apart (Hwang and Salmon 2002). Peders-

2. Hand book of statistics on Indian Securities Markets and Statistics on Mutual Funds Investment extracted from http://www.sebi.gov.in/sebiweb/ 
en and Rudholm-Alfvin (2003) and Eling and Schuhmacher (2007) also accomplish convergence between the ranks produced by numerous measures, and recognize the Sharpe ratio as exhibiting dominance to establish the ranking. In the study by (Razafitombo 2010), the author chose 15 performance measures (Jensen's alpha, beta, bull beta, bear beta, absolute performance, relative performance, number of negative periods, number of positive periods, standard deviation, max drawdown, tracking error, information ratio, Sharpe ratio, Treynor ratio and Sortino ratio) and tried to recognize which ones are the most relevant ones for evaluating mutual funds. Using a sample of 210 equity mutual funds from the Reuters-Lipper database, he examined their statistical properties, over the phase from 2000 to 2006 and noted that his investigations were clearly comprehensive, associated to other studies, as he conducted three-step tests.

The results show that correlations between the various measures are changing over time and are rather weak. From this an inference can be made that all these performance indicators were worth considering as they bring complementary information to investors. Among performance measurement indicators considered in this study, the performance analysis i.e. the market exposure, the relative performance, and the manager's skilfulness and quality of tracking especially highlights the significance of information ratios, betas and Sharpe ratios to evaluate these three dimensions. Above all, the main conclusion of the author was that performance analysis should be usefully performed with a multi-criteria approach integrating all its various aspects, i.e. including calculations over different time periods (short term, medium term and long term), and including the three dimensions of performance evaluation (relative performance, beta exposure and manager skill).

(Plantinga and Groot 2001) examine to what extent performance measures can be used as alternatives for preference functions. The study consisted of Sharpe ratio, Sharpe's alpha, the expected return measure, the Fouse index, the Sortino ratio and the upside potential ratio. It was found that the first three measures correspond to the inclinations of investors with a low degree of risk aversion, while the latter three measures match to the preferences of investors with medium and high degrees of risk aversion. Therefore, the choice of the suitable performance measure should be determined by the preference function of the investor.

The choice of a performance measure may also be justified by other considerations. A frequently used justification of a performance measure is its ability to identify the investment skills of portfolio managers. An interesting contribution to this discussion is by Kothari and Warner [2001] which focused on the capability of numerous risk-adjusted performance measures, such as the Sharpe ratio and the Jensen's alpha, to identify investment skills and concluded that the performance measures have important difficulties in detecting investment skills.

Redman, Gullett and Manakyan (2000) evaluated the risk-adjusted returns using Treynor ratio, Sharpe ratio, and Jensen's Alpha for 5 portfolios of global mutual funds and for three time periods of nine and four years $\left(19^{8} 5^{-1994}, 19^{8} 5^{-19}\right.$, , and 
1990-1994) with the benchmark of Vanguard Index 500 . During the first and second time frame, the portfolio performed better than the US markets, however during the third time frame, the earnings fell below the US index.

Astudy by Noulas and John (2005) surveyed the performance of 233 Greek equity funds amid the years $1997^{-2000}$ on a weekly basis. The performance was evaluated and ranked using the ratios of Treynor, Sharpe and Jensen. The results showed that the beta of all funds was less than one for four-year period establishing that the equity funds have neither the alike risk nor the same return.

On a global front, a study by Suzanne and Boudreaux (2007) studied ten sample portfolios of global mutual funds and examined the returns by using Sharpe's ratio for the time frame of 2000-2006. Nine out of ten of the sample mutual fund under study performed better than the benchmarked U.S. market. The portfolios which comprised of all global mutual funds did better than the portfolio which had only U.S stock mutual funds.

Using Modigliani and Modigliani (M squared) performance measure, Arugaslan and Ajay (2008) evaluated 50 extensive US global equity funds a ten-year period of 1994-2003. The results showed that risk effected the attractiveness of the fund as even though the funds had greater returns funds, they did lose attractiveness amongst the investors due to superior risk whereas the lesser return funds were attractive due to the minority of the risk.

Sathya Swaroop Debashish (2009) measured the performance of equity based mutual funds in India. There was a study of 23 schemes over a period of April 1996 to March 2009 (13 years) using various risk adjusted measures. The results show that UTI, Franklin Templeton, Prudential ICICI (in private sector) and SBI have out-performed the market portfolio with positive values, while Birla SunLife, HDFC and LIC mutual funds showed a poor below-average performance when measured against the risk-return relationship models and measures. A study by Ramesh and Dhume (2011) analyzed the performance of sector funds which were Banking, Infrastructure, FMCG, Technology and Pharmaceutical. The study focused on different performance measures. The findings of study discovered that all the except the infrastructure sector funds, other funds have outpaced the market.

Anitha (2011) assessed the performance of private and public sector mutual funds for a period of two years (2005-2007). Selected funds were studied using Statistical measures like Mean, Variance, Co-variance and Standard Deviation. The performance of all the selected funds has exhibited volatility during period of study leading it to a difficult situation to assign one particular fund that would outperform the others consistently. Patel and Prajapati (2012) estimated the performance of mutual funds in India using relative performance indices, Treynor's and Sharpe's ratio, risk-return analysis, Jensen's measure, and Fama's measure and concluded that most of the mutual funds have given positive return during the period of study. Jain (2012) investigated the performance of equity mutual funds in India using CAPM. The results show 
that in the long run, the performance of private sector companies' MFs have been far better than the public sector ones. Out of the pool of sample companies, HDFC and ICICI were the best performers whereas LIC did not perform well. Thus, the overall analysis discovers that the private sector mutual fund schemes are less risky but more rewarding when compared to the public sector ones. Annapoorna and Gupta (2013) assess mutual fund schemes' performances ranked 1 by CRISIL and give a comparison of these returns with SBI's domestic term deposit rates. For the purpose of calculations, simple statistical methods of averages and rate of returns were used. The results obtained clearly depict that, in most cases the mutual fund schemes have been unsuccessful in providing the benefit of SBI domestic term deposits.

Karrupasamy and Vanaja (2013) study and evaluate the performance of Largecap, mid cap and small cap equity mutual funds, on a risk-adjusted basis using Shrpe, Jensen and Treynor's measure for a period of three years. The findings suggest that most of the large cap and small and mid cap schemes have outperformed the category averaged as well as the benchmark indices. Also, they proposed that investors looking for an investment below 2 years can go for large cap schemes whereas those having investment beyond 3 years should invest in small and mid-cap schemes.

Bhavsar, Damani and Anvesha (2014) contribute by giving a comparative exploration of the performance of select private and public sector mutual funds and the conclusions are that mutual funds with public sector holdings have been greater performers when compared to their private sector complements. Also, with Jensen's Alpha, private sector funds have been ranked better but a higher rank was given to public sector funds under Treynor and Sharpe ratio. Arora (2015) studied the riskadjusted performance of 100 mutual funds from the period April 1, 2000 to March 31, 2008 where the results for overall performance was mixed. Sharpe ratios of $52 \mathrm{mu}$ tual fund schemes were better than that their benchmark indices. Treynor ratios of 70 per cent of mutual fund schemes were higher than their respective indices. Thus majorly, almost half of the mutual funds have performed better than their indices.

\section{DATAAND METHODOLOGY}

A sample of 100 Mutual fund schemes which are in operation for a period of five years and performing significantly well during the period of study (January ${ }^{\text {st }}, 2013$ to June $30^{\text {th }}, 2016$ ) will be selected for the present study. The time frame of the study was selected from 1 January 2013 majorly to study the direct plans of mutual funds. With effect from January ${ }_{1}{ }^{\text {st }} 2013$, it was made mandatory by SEBI that all open-ended mutual funds should have direct-plans. Direct plans help the investors to directly invest in the MFs by bypassing the distributor. As the distributor's commission is not embedded in the direct plans, their NAVs are higher. The mutual fund categories selected for the study is presented in Table 1 . The benchmark index will vary according to the category of fund. 
Table 1.: Mutual funds systematization

\begin{tabular}{|c|c|}
\hline Type of Fund & Nature of the Fund \\
\hline Large-Cap Equity funds & $\begin{array}{l}\text { Funds that invest }>75 \% \text { in CRISIL-defined } \\
\text { Large Cap Stocks for a minimum of four out of six } \\
\text { months in each period over the last } 2 \text { years. }\end{array}$ \\
\hline Small/Mid-Cap Equity funds & $\begin{array}{l}\text { Funds that invest }<45 \% \text { in CRISIL-defined } \\
\text { Large Cap Stocks for a minimum of four out of six } \\
\text { months in each period over the last } 2 \text { years. }\end{array}$ \\
\hline Diversified Equity funds & $\begin{array}{l}\text { Equity funds outside the universe of Large Cap } \\
\text { and Small \& Midcap oriented funds. }\end{array}$ \\
\hline Long term gilt funds & $\begin{array}{r}\text { Funds investing in long-term securities issued by } \\
\text { Central and state governments. }\end{array}$ \\
\hline Long term Income funds & $\begin{array}{r}\text { Funds investing in long-term corporate debt } \\
\text { papers and government securities (G-Secs). } \\
\text { Funds investing } 60 \text { per cent or more in G-Secs } \\
\text { are excluded. }\end{array}$ \\
\hline Short term Income fund & $\begin{array}{l}\text { Funds investing in short term corporate debt } \\
\text { papers, CDs, money market and GSecs. }\end{array}$ \\
\hline ELSS (Tax Savings) & $\begin{array}{l}\text { Funds aimed at enabling investors to avail tax } \\
\text { rebates under Section } 8 \circ \text { C of the Income Tax Act. }\end{array}$ \\
\hline
\end{tabular}

Source: Autors

The data collected is for the daily closing NAVs of the mutual funds along with their benchmark index, expense ratios, type of fund, the ratings and returns. The sample of 100 funds selected is some of the top rated funds as per CRISIL, Value research and Morningstar India in their individual fund categories. The data is extracted from Datastream and Association of Mutual Funds in India.

\subsection{Measures for Performance Evaluation}

Absolute Returns: A return is gain or loss of a security or asset in which the investment is made during a particular period of time. The returns also consist of the capital gains and income on an investment and is usually quoted as a percentage.

Daily returns () : The daily returns for the mutual funds are calculated using the historical Net Asset Values (NAVs) as follows where denotes the Net Asset Value of the scheme at time and denotes the Net Asset value of the scheme at i.e. a day prior. We have used log returns as they are time consistent or time additive. Also, if the log returns are normally distributed, adding the log returns would produce an end log return which is also normally distributed.

Average daily returns: The average returns or the mean growth rate of the funds are calculated using:

Annualized average returns: Since the daily returns are natural logarithmic returns, the annual average returns are calculated as follows:

260 represents an average of 260 trading/working days in a year on which the values of the NAVs will change. 
Standard deviation: Standard deviation is a measure of dispersion of a data set from its mean. The more spread the data, higher would be the deviation. It gives us the historical volatility which is used by the investors to apprehend the amount of expected volatility in future.

The daily standard deviation for the mutual funds are calculated as:

Where, represents standard deviation of the scheme, is the daily return, is the mean return, is the total number of values in the population.

The annual standard deviation is calculated using:

Sharpe Ratio: Sharpe Ratio is a risk-adjusted measure of return used to evaluate a portfolio's returns. It is a measure that gives the investor an estimation of the average returns earned in excess of risk-free rate of return per unit of total risk or volatility. The ratio is calculated as:

Where, is the mean scheme return, is the risk free rate of return and is the standard deviation of the returns.

Treynor Ratio: The Treynor ratio is a measurement of risk-adjusted performance measure for a portfolio. It measures the excess returns the fund earns over and above the risk free rate of returns with an adjustment to the volatility in the market measure in the form of Beta coefficient of the portfolio. It is also a measurement of efficiency adjusting for the market (systematic) risk measured by Beta. Beta is a measure which measures the sensitivity of the scheme to market movements to gauge the risk. The Treynor ratio is calculated as:

Where, is the mean scheme return, is the risk free rate of return and is the Beta coefficient of the returns. For calculation purposes, the Beta of the mutual fund schemes have been extracted from Thomson Reuters. Similar to Sharpe Ratio, the higher the Treynor Ratio, the better is the performance of the Scheme.

Jensen's Alpha: It is a measure of absolute performance on a risk-adjusted basis. It represents the average return a scheme would earn over and above the returns are predicted by the Capital Asset Pricing Model (CAPM) given the portfolio's beta and the mean market return. Jensen's Alpha is calculated as:

Where, is the mean scheme return, is the risk free rate of return, is the Beta coefficient of the returns, is the average returns of the benchmarked index.

Value at Risk: Value at Risk (VaR) can be described as the maximum loss in the value of a portfolio or an asset within a determined time period and with a pre-defined probability rate or confidence level under regular market conditions. It is the maximum level of loss that the fund will incur given a particular threshold of probability. In case we are calculating the daily VaR, we estimate the worst expected loss that the company can incur next trading day.

Value at Risk can be calculated as:

Where, is the mean scheme return, is the confidence interval and is the standard deviations of the returns. 


\section{RESULTS AND ANALYSIS}

\subsection{Sharpe Ratio}

We computed Sharpe ratio for the former 36-month period by dividing the fund's annualized excess returns over the risk-free rate by its annualized standard deviation. Since Standard deviation (also known as volatility) can't be negative, Sharpe ratio is negative in case the funds' returns are lesser than the risk-free rate of return. Negative Sharpe ratios are problematic as, counter-intuitively, whilst returns are negative, bigger risk produces a higher Sharpe ratio. Additionally, a negative Sharpe ratio isn't significant because the ratio is designed to help put an outlay's excess returns into milieu, and when a fund has undesirable returns, it is perceptibly not beating the risk-free rate. The results are reported in Table 2.

Table 2.: Results of Sharpe Ratio

\begin{tabular}{|c|c|c|c|c|c|}
\hline \multicolumn{6}{|c|}{ Percentage of Schemes having } \\
\hline $\begin{array}{l}\text { Name of the } \\
\text { scheme }\end{array}$ & $\begin{array}{r}\text { Positive } \\
\text { Ratios }\end{array}$ & $\begin{array}{r}\text { Negative } \\
\text { ratios }\end{array}$ & $\begin{array}{r}\text { Highest } \\
\text { Ratio }\end{array}$ & Lowest Ratio & No.of Funds \\
\hline $\begin{array}{l}\text { Diversified } \\
\text { Equity }\end{array}$ & $88.9 \%$ & $11.1 \%$ & 1.200 & -0.298 & 18 \\
\hline $\begin{array}{l}\text { ELSS (Tax } \\
\text { Savings) }\end{array}$ & $100 \%$ & ○\% & 1.114 & 0.109 & 9 \\
\hline Large-Cap & $82.35 \%$ & $17.65 \%$ & 0.765 & $-0.5^{14}$ & 17 \\
\hline Long term gilt & $81.25 \%$ & $18.75 \%$ & 0.724 & -0.085 & 16 \\
\hline $\begin{array}{l}\text { Long term } \\
\text { Income funds }\end{array}$ & $100 \%$ & $\circ \%$ & 0.825 & $0.07^{3}$ & 8 \\
\hline $\begin{array}{l}\text { Short term } \\
\text { Income fund }\end{array}$ & $100 \%$ & $\circ \%$ & 1.147 & 0.010 & 8 \\
\hline $\begin{array}{l}\text { Small/Mid- } \\
\text { Cap }\end{array}$ & $100 \%$ & $\circ \%$ & 1.659 & 0.213 & 11 \\
\hline $\begin{array}{l}\text { Ultra-short } \\
\text { term debt fund }\end{array}$ & $100 \%$ & $\circ \%$ & 2.519 & 0.574 & 12 \\
\hline
\end{tabular}

Source: Autors`

In our sample we observe that $11.1 \%$ of Diversified Equity, $17.65 \%$ of Large Cap funds and $18.75 \%$ of Long term gilt funds have a negative Sharpe ratio. This can be because that the funds did not perform well in the shorter duration of 36 months and provided a return less than the risk-free rate of return. However, funds under the ELSS scheme, Long tern Income funds, Short term income funds, small and mid cap funds and ultra short term debt, were able to provide a positive excess return over the risk free rate of return. This shows that if an investor is aiming to invest for a shorter period of time (say 3 years), he can look at these type of funds. According to the Sharpe Ratio, we see that Ultra-short term debt funds have the highest Sharpe Ratio of $2.5^{19}$ which is very good and thus it is preferable to invest in ultra-short term debt funds as they have provided excess returns over the risk free index. 


\subsection{Treynor Ratio}

The Treynor ratio is a function of beta, which measures a security's sensitivity to movements in the market, to gauge risk. Since the Treynor ratio is a function of beta, it also shares beta's caveats. Along with the pervasive condition that beta is grounded on historical performance and therefore has restricted usefulness as a predictor of imminent performance, the practicality of beta is also wholly dependent upon the level of correlation with its market benchmark. We use Treynor ratio to equate two schemes within the same fund category or to compare a scheme's ratio with that of category average or market benchmark. The results are presented in Table 3.

Table 3.: Results of Treynor Ratio

\begin{tabular}{|c|c|c|c|c|c|}
\hline \multicolumn{6}{|c|}{ Percentage of schemes having } \\
\hline $\begin{array}{l}\text { Name of the } \\
\text { scheme }\end{array}$ & $\begin{array}{r}\text { Positive } \\
\text { ratios }\end{array}$ & $\begin{array}{r}\text { Negative } \\
\text { ratios }\end{array}$ & $\begin{array}{r}\text { Highest } \\
\text { Ratio }\end{array}$ & Lowest Ratio & No.of Funds \\
\hline $\begin{array}{l}\text { Diversified } \\
\text { Equity }\end{array}$ & $88.9 \%$ & $11.1 \%$ & 0.155 & -0.04 .8 & 18 \\
\hline $\begin{array}{l}\text { ELSS (Tax } \\
\text { Savings) }\end{array}$ & $100 \%$ & $\circ \%$ & 0.176 & 0.017 & 9 \\
\hline Large-Cap & $82.35 \%$ & $17.65 \%$ & 0.010 & -0.092 & 17 \\
\hline Long term gilt & $81.25 \%$ & $18.75 \%$ & 0.025 & -0.001 & 16 \\
\hline $\begin{array}{l}\text { Long term } \\
\text { Income funds }\end{array}$ & $100 \%$ & ०\% & 0.010 & 0.001 & 8 \\
\hline $\begin{array}{l}\text { Short term } \\
\text { Income fund }\end{array}$ & $100 \%$ & ०\% & 0.012 & 0.001 & 8 \\
\hline $\begin{array}{l}\text { Small/Mid- } \\
\text { Cap }\end{array}$ & $100 \%$ & $\circ \%$ & 0.169 & 0.024 & 11 \\
\hline $\begin{array}{l}\text { Ultra-short } \\
\text { term debt fund }\end{array}$ & $100 \%$ & ०\% & 0.040 & 0.003 & 12 \\
\hline
\end{tabular}

Source: Autors

If the portfolio return is less than the risk-free rate although the fund's beta remains positive (inferring that the fund removed the systematic risk but didn't surpass the risk-free rate), funds will have negative Treynor ratios. Since, all the funds have provided positive returns, tis explanation holds true. In our sample, we see that $11.1 \%$ of Diversified Equity, $17.65 \%$ of Large Cap funds and $18.75 \%$ of Long term gilt funds have a negative Treynor ratio. This indicates that these funds haven't sufficiently compensated their investors for the risk they have subjected them to and that its returns have been lesser than the risk-free rate of return during the former 3 years. 


\subsection{Jensen's Alpha}

Alpha can be described as an extent of a manager's ability or skill to add value over a passive benchmark. Also, it is significant to consider that alpha first alters for the degree of market risk undertaken by the manager. Alpha is whatever remains after the market risk (beta) is netted out. The results appear in Table 4.

Table 4.: Results of Jensen's Alpha

\begin{tabular}{|c|c|c|c|c|c|}
\hline \multicolumn{6}{|c|}{ Percentage of schemes having } \\
\hline $\begin{array}{l}\text { Name of the } \\
\text { scheme }\end{array}$ & $\begin{array}{r}\text { Positive } \\
\text { ratios }\end{array}$ & $\begin{array}{r}\text { Negative } \\
\text { ratios }\end{array}$ & $\begin{array}{r}\text { Highest } \\
\text { Ratio }\end{array}$ & Lowest Ratio & No.of Funds \\
\hline $\begin{array}{l}\text { Diversified } \\
\text { Equity }\end{array}$ & $83.3 \%$ & $16.7 \%$ & 0.160 & -0.096 & 18 \\
\hline $\begin{array}{l}\text { ELSS (Tax } \\
\text { Savings) }\end{array}$ & $89 \%$ & $11 \%$ & 0.129 & -0.008 & 9 \\
\hline Large-Cap & $82.35 \%$ & $17.65 \%$ & 0.012 & -0.136 & 17 \\
\hline Long term gilt & $56.25 \%$ & $43.75 \%$ & 0.023 & -0.015 & 16 \\
\hline $\begin{array}{l}\text { Long term } \\
\text { Income funds }\end{array}$ & $38 \%$ & $63 \%$ & 0.018 & -0.008 & 8 \\
\hline $\begin{array}{l}\text { Short term } \\
\text { Income fund }\end{array}$ & $88 \%$ & $13 \%$ & 0.013 & -0.007 & 8 \\
\hline $\begin{array}{l}\text { Small/Mid- } \\
\text { Cap }\end{array}$ & $100 \%$ & $\circ \%$ & 0.210 & 0.014 & 11 \\
\hline $\begin{array}{l}\text { Ultra-short } \\
\text { term debt fund }\end{array}$ & $100 \%$ & $\circ \%$ & 0.016 & 0.004 & 12 \\
\hline
\end{tabular}

Source: Autors

For calculating Jensen's Alpha, the bond funds and equity funds have two separate benchmark indexes. The benchmark index for equity funds is Nifty 500 with an average annualized returns of $11.36 \%$ and for bond funds, it is S\&P BSE India Agency Bond Index with an average annualized returns of $9.34 \%$. The beta considered for the calculation of Jensen's alpha has been separately considered for both equity and debt mutual funds and have been correspondingly correlated to their respective benchmark. We report that $16.7 \%$ of Diversified Equity, $11 \%$ of ELSS schemes, $17.65 \%$ of Large Cap funds, $43.75 \%$ of Long term gilt funds, 63\% of long-term Income funds and $13 \%$ of short term income funds have a negative Jensen's Alpha. The reason is that the returns generated by the schemes did not compensate adequately over the average market return grounded on the beta of the scheme. Since the alpha of the market is zero, the negative alphas mean that the schemes are underperforming the market. Another factor for negative alpha can be that the manager has undertaken excess risks and was able to generate only a marginal outperformance with the benchmark. 


\subsection{Value-at-Risk}

The calculation of Value-at-Risk is on a daily basis and a negative daily return (expressed in percent) is expected to occur about 1 out of a 260 trading days. An investor often desires to compute $\mathrm{VaR}$ for periods lengthier than one day, as it might not be possible to close a position in one day, particularly if it is illiquid. If, over and above normality, we assume that returns are consecutively independent, subsequently the standard deviation of longer-period returns surges with the square root of time. A serious shortcoming of parametric VaR is that it underrates the frequency of "extreme events," such as results several standard deviations away from the average. A reason for this is that asset return distributions demonstrate "fat tails," which means that more number of outcomes are positioned in the tails instead of the center of the distribution. The results are reported in Table 5 .

Table 5.: Results of Value at Risk

\begin{tabular}{|l|r|r|r|}
\hline \multicolumn{1}{|c|}{ Name of the scheme } & Highest VaR & Lowest VaR & No.of Funds \\
\hline Diversified Equity & $-2.12 \%$ & $-1.14 \%$ & 18 \\
ELSS (Tax Savings) & $-1.62 \%$ & $-1.33 \%$ & 9 \\
Large-Cap & $-2.08 \%$ & $-0.14 \%$ & 17 \\
Long term gilt & $-0.58 \%$ & $-0.42 \%$ & 16 \\
Long term Income funds & $-0.52 \%$ & $-0.25 \%$ & 8 \\
Short term Income fund & $-1.71 \%$ & $-0.09 \%$ & 8 \\
Small/Mid-Cap & $-1.82 \%$ & $-0.25 \%$ & 11 \\
Ultra-short term debt & $-0.06 \%$ & $-0.01 \%$ & 12 \\
fund & & & \\
\hline
\end{tabular}

Source: Autors`

We see that the VaR for equity funds is higher than that of debt funds. This is due to the higher returns of equity funds. Even though the standard deviations for the equity funds are higher as well, but the returns are relatively more in case of equity funds. The highest Value-at-Risk is $2.12 \%$ which is for diversified equity while the lowest $\mathrm{VaR}$ is $1.14 \%$ for the same class of funds. Ultra-short term debt are expected to have the lowest VaR of just $0.01 \%$ and even the maximum for that class of funds is $0.06 \%$. This means that the potential losses in any given day for that fund is not more than $0.06 \%$ for those funds.

\subsection{Expense Ratio}

Expense ratios are also a key performance measure as it is possible that the expense ratios might eat away some of the fund's returns. An expense ratio is also a measure to show how efficient are returns over and above what investors paying for the management of its fees. Table 6 reflects extreme expense ratio for our sample funds. 
Table 6.: Results of value, expense ratio, cumulative ranking and annualised returns for mutual funds sample

\begin{tabular}{|c|c|c|c|c|c|}
\hline Category & Value & $\begin{array}{c}\text { Expense } \\
\text { Ratio }\end{array}$ & Name of the fund & $\begin{array}{l}\text { Cumulative } \\
\text { Ranking }\end{array}$ & $\begin{array}{c}\text { Annualised } \\
\text { Returns }\end{array}$ \\
\hline $\begin{array}{l}\text { Diversified } \\
\text { Equity }\end{array}$ & Lowest & 0.32 & $\begin{array}{r}\text { Birla Sun Life India } \\
\text { GenNext Fund-Growth }\end{array}$ & 12 & $18.1 \%$ \\
\hline $\begin{array}{l}\text { Diversified } \\
\text { Equity }\end{array}$ & Highest & 2.36 & $\begin{array}{r}\text { UTI-MNG Fund- } \\
\text { Growth }\end{array}$ & 3 & $22.6 \%$ \\
\hline $\begin{array}{l}\text { ELSS (Tax } \\
\text { Savings) }\end{array}$ & Lowest & 1.28 & $\begin{array}{l}\text { Axis Long Term Equity } \\
\text { Fund-Growth }\end{array}$ & 1 & $23.7 \%$ \\
\hline $\begin{array}{l}\text { ELSS (Tax } \\
\text { Savings) }\end{array}$ & Highest & $2.5^{6}$ & $\begin{array}{r}\text { DSP BlackRock Tax } \\
\text { Saver Fund-Direct- } \\
\text { Growth }\end{array}$ & 6 & $18.6 \%$ \\
\hline Large-Cap & Lowest & 1 & $\begin{array}{l}\text { Kotak Select Focus } \\
\text { Fund-Growth-Direct }\end{array}$ & 1 & $19.5 \%$ \\
\hline Large-Cap & Highest & $2 \cdot 4^{1}$ & $\begin{array}{l}\text { ICICI Prudential Top } \\
100 \text { Fund-Growth }\end{array}$ & 9 & $14.1 \%$ \\
\hline $\begin{array}{l}\text { Long term } \\
\text { gilt }\end{array}$ & Lowest & 0.3 & $\begin{array}{l}\text { Birla Sun Life Gilt Plus- } \\
\text { PF-Growth-Direct }\end{array}$ & 5 & $10.3 \%$ \\
\hline $\begin{array}{l}\text { Long term } \\
\text { gilt }\end{array}$ & Highest & 1.4 & $\begin{array}{r}\text { Kotak Gilt Investment- } \\
\text { Growth }\end{array}$ & 16 & $7.9 \%$ \\
\hline $\begin{array}{l}\text { Long term } \\
\text { Income } \\
\text { funds }\end{array}$ & Lowest & 0.59 & $\begin{array}{l}\text { Tata Dynamic Bond } \\
\text { Fund-Direct-Growth }\end{array}$ & 2 & $10.9 \%$ \\
\hline $\begin{array}{l}\text { Long term } \\
\text { Income } \\
\text { funds }\end{array}$ & Highest & 1.85 & $\begin{array}{l}\text { Reliance Income Fund- } \\
\text { Direct Growth-Growth- } \\
\text { Growth }\end{array}$ & 9 & $8.6 \%$ \\
\hline $\begin{array}{l}\text { Short term } \\
\text { Income } \\
\text { fund }\end{array}$ & Lowest & 0.25 & $\begin{array}{l}\text { Tata Short Term Bond } \\
\text { Fund-Direct-Growth }\end{array}$ & 1 & $9.8 \%$ \\
\hline $\begin{array}{l}\text { Short term } \\
\text { Income } \\
\text { fund }\end{array}$ & Highest & 1.08 & $\begin{array}{r}\text { IDFC Tax Advantage } \\
\text { (ELSS) Fund-Direct- } \\
\text { Dividend }\end{array}$ & 8 & $8.5 \%$ \\
\hline $\begin{array}{l}\text { Small/ } \\
\text { Mid-Cap }\end{array}$ & Lowest & 0.25 & $\begin{array}{r}\text { Franklin India Smaller } \\
\text { Companies Fd-Direct- } \\
\text { Growth }\end{array}$ & 2 & $31.7 \%$ \\
\hline $\begin{array}{l}\text { Small/ } \\
\text { Mid-Cap }\end{array}$ & Highest & $2 \cdot 5^{3}$ & $\begin{array}{l}\text { DSP BlackRock } \\
\text { Strategic Bond Fd- } \\
\text { Direct-Growth }\end{array}$ & 9 & $9.5 \%$ \\
\hline $\begin{array}{l}\text { Ultra-short } \\
\text { term debt } \\
\text { fund }\end{array}$ & Lowest & 0.1 & $\begin{array}{r}\text { Birla Sun Life Floating } \\
\text { Rate-LT-Direct- } \\
\text { Growth }\end{array}$ & 5 & $9.5 \%$ \\
\hline $\begin{array}{l}\text { Ultra-short } \\
\text { term debt } \\
\text { fund }\end{array}$ & Highest & $0.7^{8}$ & $\begin{array}{r}\text { Franklin India Low } \\
\text { Duration Fund-Direct- } \\
\text { Growth }\end{array}$ & 2 & $9.9 \%$ \\
\hline
\end{tabular}

Source: Autors`

We observe that the expense ratio for our sample mutual funds varies from $0.1 \%$ to $2.56 \%$. The expense ratio for equity funds vary much more than that of debt funds and hold a higher percentage. The expense ratio for debtfunds is as low as $0.1 \%$ however for equity funds it is $0.25 \%$. Also, the highest expense ratio for equity funds is as high as $2.56 \%$ whereas for 
debt funds, it is just 1.85\% which is within the stipulated SEBI limits on expense ratios. Equity funds require more attention of the management so they command higher expense ratios. Index funds and bond funds necessitate comparatively much less work thus they typically have lower expense ratios. Along with that, the expense ratios are subject to SEBI-imposed limits. Debt funds are allowed an expense ratio of 0.25 percentage points lesser than equity funds. Another observation that can be made is that it is not necessary that the fund with the lowest expense ratio gives the lowest return or vice-versa. As per our cumulative ranking index, we see that many funds are ranked 1 (i.e. best in the fund category) and still have the lowest expense ratio. These funds are Axis Long Term Equity Fund-Growth, Kotak Select Focus Fund-Growth-Direct, Tata Short Term Bond Fund-Direct-Growth and Franklin India Smaller Companies Fund-Direct-Growth. A similarity in these schemes is that all these funds are direct funds and also they have given significantly higher annualised returns.

\subsection{Comprehensive Rankings}

The 100 funds sampled in the study have been assigned comprehensive rankings on the basis of various risk adjusted performance ratios and value at risk. All the funds have been first ranked individually on the basis of Sharpe ratio, Treynor ratio and Jensen's Alpha, where the funds with the highest ratios are ranked 1 and the ones with the lowest ratios are ranked lower (with 1 being the best ranking). Then the funds are also ranked on the basis of $\mathrm{VaR}$ with the fund with the lowest $\mathrm{VaR}$ has been ranked the highest (given the ranking of 1 ) and the fund with the highest $V a R$ has been given the lowest rankings. After assigning individual ranking to the funds, a sum total of all the rankings helps derive the comprehensive rankings of the funds. Therefore, it is not necessary that a fund with the highest returns or the lowest standard deviation has the best ranking, neither it is necessary that a fund has to have the highest risk-adjusted performance ratio to have the lowest VaR. Further, it is to be noted that all the rankings of the ratios and $\mathrm{VaR}$ have been assigned equal weights. Table 7 . lists best ranked mutual funds in each category while Appendix 1 reports overall ranking for top ten funds across all categories.

Table 7.: Best ranked mutual funds per category

\begin{tabular}{|l|r|}
\hline \multicolumn{1}{|c|}{ Fund Category } & Name of the scheme \\
\hline Diversified Equity & Franklin Build India Fund-Direct-Growth \\
ELSS (Tax Savings) & L\&T Tax Advantage Fund-Direct-Growth \\
Large-Cap & HDFC High Interest Fd-Dynamic-Direct-Growth \\
Long term gilt & Kotak Gilt Investment Prov Fd \& Trust-Growth \\
Long term Income funds & Reliance Short Term Fund-Growth \\
Short term Income fund & Reliance Income Fund-Direct Growth-Growth-Growth \\
Small/Mid-Cap & Kotak Emerging Equity Scheme-Growth-Direct \\
Ultra-short term debt fund & DHFL Pramerica ShTm Floating Rate-Dir-Growth \\
\hline
\end{tabular}

Source: Autors 


\section{CONCLUSION}

This study assesses the performance of Indian mutual fund schemes using Sharpe ratio, Treynor ratio, Jensen's Alpha and Value at Risk for a sample of 100 Indian mutual fund schemes. The study period is from January 2013 to June 2016. The sample comprises of 18 diversified equity schemes, 9 tax saving schemes, 17 large cap funds, 16 long term gilt, 8 long term income, 8 short term income funds, 11 small/ mid cap funds and 12 ultra-short term funds. The results of Sharpe ratio and Treynor ratio reflect that 90 percent of the schemes have performed better than their benchmarks which reflect that during this period that the funds have done fairly well and have outperformed the market. As per the Jensen's Alpha, the returns generated by 79 schemes compensated adequately over the average market return given the beta of the scheme. Majorly, the schemes with the negative Sharpe Ratio and Treynor Ratio are diversified equity, long term gilt or large cap equity funds. This implies that during the study period, a vast majority of long, short and ultra short debt funds, ELSS and Mid/small cap funds have consistently performed better. Hence, the investors who are interested in consistent returns may choose investment in these schemes. Additionally, the Value-at-Risk for mutual funds has been studied which is the potential loss for a fund in any given day. The Value at Risk for equity based mutual funds are higher than that of debt fund which shows that even though the equity funds have higher potential for returns but on the other hand, the downside risk is also comparatively higher. It is important for an investor to not only identify the category of fund for his investment but also pick-up the best fund in that category. This is because even within a category, the returns for the funds might vary vastly from scheme to scheme. 


\section{REFERENCES}

Annapoorna, M.S. and Pradeep K. Gupta. "A comparative analysis of returns of mutual fund schemes ranked 1 by CRISIL". Tactful Management Research Journal 2.1 (2013): 1-6. Retrieved from http://tmgt.lsrj. in/UploadedArticles/84.pdf

Arora, Kavita. "Risk-Adjusted Performance Evaluation of Indian Mutual Fund Schemes". SAGE Publications 19.1 (2015): 79-94. Retrieved from http://par.sagepub.com/content/19/1/79.full.pdf+html

Arugaslan and Ajay., Evaluating large US-based equity mutual funds using risk-adjusted performance measures, International Journal of Commerce and Management, 17,1/2, pp.6-24,2008.

Bhavsar, A. C., \& Damani, A. (2014). A comparative study of the performance of selected mutual fund growth schemes from the private sector and public sector schemes in india. Anvesha, $7_{(1)}{ }_{1-1-9}$. Retrieved from http://search.proquest.com.spjain.idm.oclc.org/docview/154.0771275? accountid $=162730$

Boudreaux and Suzanne, Empirical Analysis of International Mutual Fund performance, International Business \& Economics Research Journal, 6, (2007): 19-22

Canadian Securities Administrators. Understanding Mutual Funds. 2016. Web. 26 Oct. 2016. Retrieved from http://www.osc.gov.on.ca/documents/en/Investors/res_mutual-funds_en.pdf

CRISIL Research(2016). For The Quarter Ended June 30, 2016. Mumbai. CRISIL Mutual Fund Ranking. Retrieved from http://www.crisil.com/pdf/capitalmarket/CRISIL_Mutual_Fund_Ranking-June-2016.pdf

Debasish Sathya Swaroop (2009), Investigating Performance of Equity-based Mutual Fund Schemes in Indian Scenario, KCA Journal of Business Management. VOL. 2, ISSUE 2.

Vasantha, S, Uma Maheswari, and KSubashini. "Evaluating The Performance Of Some Selected Open Ended Equity Diversified Mutual Fund In Indian Mutual Fund Industry". www.rroij.com. N.p., 2013. Web. 4. Sept. 2016.

Eling, M. and F. and Schuhmacher., Does the choice of performance measure influence the evaluation of hedge funds? Journal of Banking and Finance 31(9), (2007): 2632-2647

Grau-Carles, Pilar et al. "Different Risk-Adjusted Fund Performance Measures: A Comparison". Economicsejournal.org. N.p., 2009. Web. 3 Nov. 2016.

Here is how demonetisation will affect the mutual fund industry - Cafemutual.com. (2016). Cafemutual. Retrieved 21 November 2016, from http://cafemutual.com/news/trends/768-here-is-howdemonetisation-will-affect-the-mutual-fund-industry

Hwang S., and M. Salmon., An analysis of performance measures using copulae. InPerformance Measurement in Finance: firms, funds and managers. J. Knight and S. Satchel, eds. Oxford, U.K.: Butterworth-Heinemann, 2002.

Jain, Sahil. "Analysis Of Equity Based Mutual Funds In India". IOSR Journal of Business and Management (IOSRJBM) 2278-487XVolume 2.1 (2012): PP 01-04. Retrieved from: http://iosrjournals.org/iosr-jbm/ papers/vol2-issue1/Ao210104.pdf

Kalpesh P Prajapati and Mahesh K Patel, Comparative Study On Performance Evaluation of Mutual Fund Schemes Of Indian Companies, Researchers world, Journal of Arts, Science \& Commerce Vol-III, Issue3(3), July 2012, (2012): 47-59

Karrupasamy, R. and V. Vanaja. "A Study On The Performance Of Selected Large Cap And Small \& Mid Cap Mutual Fund Schemes In India". The International Journal of Management 2.3 (2013): 7-13. Retrieved from: http://www.theijm.com/volzissue3/2.222.pdf 
Kidd, Deborah. "Risk-Adjusted Performance Measures: A Case Study". Investment risk and performancen. pag. Retrieved from: http://www.cfapubs.org/doi/pdf/10.2469/irpn.02012.n1.7

Kothari, S.P. and Jerold B. Warner, "Evaluating mutual fund performance", Journal of finance, Vol. $5^{6}$, No. 1, pp. (2001): 1985-2010

Markowitz, H., Portfolio selection. Journal of Finance z(March), (1952): 77-91

Noulas, John and John, Performance of mutual funds. Managerial finance, 31(2), (2005): $101-112$

Pedersen, C. S., and T. Rudholm-Alfvin., Selecting risk-adjusted shareholder performance measure. Journal of Asset Management 4.(3), (2003): 152-172

Plantinga, A., and D. De Groot., Risk-adjusted performance measures and implied risk attitudes. Journal of Performance Measurement 6, (2002): 9-22

Pournima S. Shenvi Dhume and Prof. B. Ramesh, "Performance Analysis of Indian Mutual Funds with a Special Reference to Sector Funds", The Indian Journal of Commerce, Vol. 64, No. 9, (2011) JulySeptember 2011.

Razafitombo, Hery. "EDHEC-Risk - A Statistical Analysis Of Mutual Fund Performance Measures: The Relevance Of Irs, Betas, And Sharpe Ratios". Edhec-risk.com. N.p., 2010. Web. 1 Oct. 2016.

R. Anitha, T. Devasenathipathi and C. Radhapriya, "Comparative Analysis of Market Returns and Fund Flows with Reference to Mutual Funds" International Journal Of Research In Commerce, It \& Management, Volume no. 1, Issue no. 4, September, 2011.

Redman, A. L., Gullett, N. S., \& Manakyan, H., The performance of global and international mutual funds. Journal of Financial and Strategic Decisions, 13(1), (2000): $75^{-85}$

Simons, Katerina, The Use Of Value At Risk By Institutional Investors. New England Economic Review, 2000. Print.

Sharma, Dr Preeti and Rao, D. N. A Study of Risk Orientation of Retail Investors in Indian Mutual Fund Industry with Special Reference to Rajasthan, India. (2014) Retrieved from SSRN: http://dx.doi. org/10.2139/ssrn.24.67951 


\section{APPENDIX 1}

\begin{tabular}{|c|c|c|c|c|c|c|c|c|c|c|}
\hline 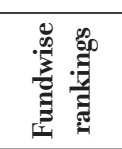 & - & N & m & F & 10 & 6 & $\Gamma$ & $\infty$ & $a$ & $\stackrel{\circ}{\circ}$ \\
\hline 总 & $=$ & 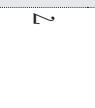 & $I$ & 6 & $\mathcal{I}$ & $\dddot{Z}$ & $\stackrel{\circ}{ }$ & $m$ & $a$ & 누 \\
\hline 㩆 & - & $\alpha$ & 6 & 20 & m & F & $\sigma$ & ㅇ & $\infty$ & $N$ \\
\hline 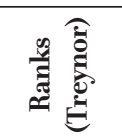 & $\tau$ & $m$ & $\alpha$ & 20 & 6 & F & $\sim$ & $\dddot{7}$ & 음 & $\infty$ \\
\hline 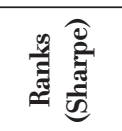 & - & o & $m$ & F & 20 & 6 & $a$ & $\sim$ & $\infty$ & $\stackrel{\circ}{9}$ \\
\hline 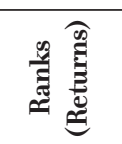 & $\tau$ & N & 6 & LO & $m$ & F & $\infty$ & $\stackrel{9}{ }$ & $a$ & $\sim$ \\
\hline 总 & ્ָ & $\stackrel{\leftarrow}{\stackrel{\sim}{\circ}}$ & 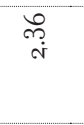 & $\stackrel{20}{\stackrel{2}{+}}$ & 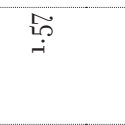 & 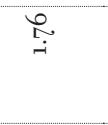 & $\underset{+}{F}$ & $\underset{\sim}{\tilde{N}}$ & $\begin{array}{l}\stackrel{L}{\circ} \\
\dot{0}\end{array}$ & 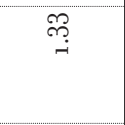 \\
\hline 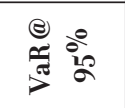 & $\begin{array}{l}\stackrel{0}{\circ} \\
i \vec{i}\end{array}$ & $\stackrel{\circ}{\circ}$ & i্ & ڤั & 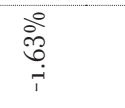 & 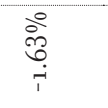 & 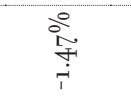 & $\begin{array}{l}\circ \\
\stackrel{0}{0} \\
i \\
i\end{array}$ & 운 & مْ \\
\hline$\stackrel{0}{0} \frac{\pi}{2}$ & \begin{tabular}{l}
$\stackrel{0}{0}$ \\
\hdashline \\
0
\end{tabular} & $\begin{array}{l}\stackrel{\circ}{\overparen{0}} \\
\stackrel{7}{0}\end{array}$ & $\underset{\widetilde{T}}{\stackrel{7}{0}}$ & $\stackrel{\overparen{P}}{0}$ & $\stackrel{+1}{\dddot{0}}$ & 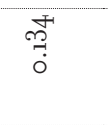 & $\begin{array}{l}\text { वू } \\
\text { ơ } \\
\dot{0}\end{array}$ & $\begin{array}{l}\text { ă } \\
\text { o. } \\
\text { o }\end{array}$ & $\begin{array}{l}\text { 2. } \\
\text { ô } \\
\dot{0}\end{array}$ & $\begin{array}{l}2 \\
0 \\
0 \\
0\end{array}$ \\
\hline 离。 & 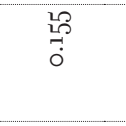 & $\begin{array}{l}\text { 눙 } \\
\text { 웅 }\end{array}$ & 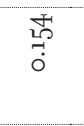 & $\stackrel{\mathscr{m}}{\stackrel{\leftrightarrow}{0}}$ & $\stackrel{\mathscr{D}}{\stackrel{0}{0}}$ & $\stackrel{\overparen{3}}{0}$ & 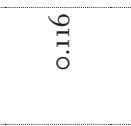 & $\begin{array}{l}\stackrel{2}{0} \\
0 \\
\dot{0}\end{array}$ & $\stackrel{\overrightarrow{0}}{\square}$ & 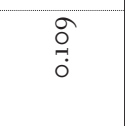 \\
\hline 营 & ্ְণ & $\stackrel{\circ}{\stackrel{\circ}{\leftrightarrows}}$ & $\underset{乛}{\overparen{్}}$ & 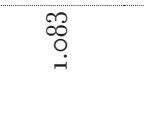 & $\underset{\circ}{\sigma a}$ & ֻ̊ & $\begin{array}{l}\text { O } \\
\infty \\
0 \\
0\end{array}$ & $\begin{array}{c}\widetilde{0} \\
\stackrel{0}{0} \\
0\end{array}$ & $\begin{array}{c}\text { F } \\
\circ \\
0 \\
0\end{array}$ & 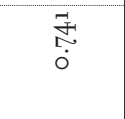 \\
\hline صَّ & $\underset{\text { ָָ }}{\text { Z }}$ & ণ্ণ & $\begin{array}{l}\text { a } \\
\dot{0}\end{array}$ & $\stackrel{\Re}{\rightarrow}$ & ণ্ণ & 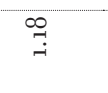 & ণ্+i & 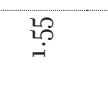 & $\varsubsetneqq$ & $\underset{I}{\longrightarrow}$ \\
\hline 急 $\frac{己}{0}$ & 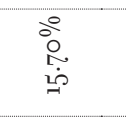 & $\begin{array}{l}\text { के } \\
\text { ஸे } \\
\dot{j}\end{array}$ & $\begin{array}{l}\circ \\
\stackrel{\circ}{\dot{j}}\end{array}$ & 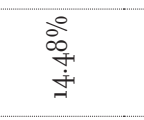 & $\begin{array}{l}0 \\
0 \\
0 \\
0 \\
0\end{array}$ & 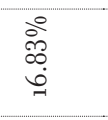 & $\begin{array}{l}\stackrel{0}{0} \\
\stackrel{0}{\circ} \\
\text { i̊ }\end{array}$ & 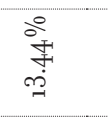 & $\begin{array}{l}\stackrel{0}{+} \\
\stackrel{+}{+} \\
\dot{j}\end{array}$ & $\begin{array}{l}\dot{0} \\
\dot{0} \\
\dot{0} \\
\dot{0}\end{array}$ \\
\hline 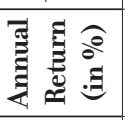 & 离 & $\begin{array}{l}\text { o̊ } \\
\stackrel{0}{0} \\
\dot{\alpha}\end{array}$ & $\begin{array}{l}\text { ì } \\
\text { ปें } \\
\text { มे }\end{array}$ & 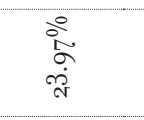 & 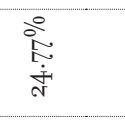 & $\begin{array}{l}\stackrel{2}{0} \\
\text { oे } \\
\dot{j} \\
\dot{d}\end{array}$ & 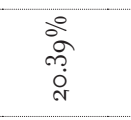 & $\begin{array}{l}\stackrel{\circ}{\alpha} \\
\stackrel{2}{=}\end{array}$ & $\begin{array}{l}\stackrel{0}{\circ} \\
\text { ๙ิ } \\
\stackrel{\text { ๙े }}{ }\end{array}$ & 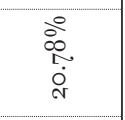 \\
\hline है & 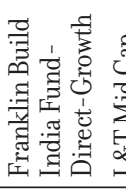 & 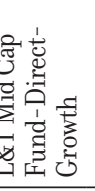 & 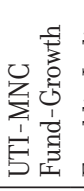 & 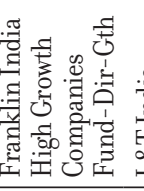 & 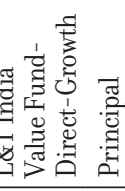 & 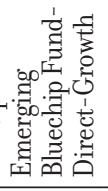 & 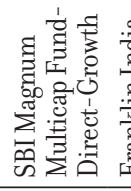 & 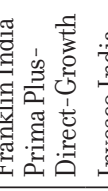 & 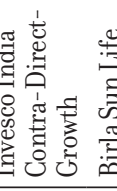 & 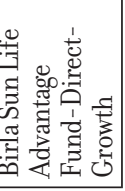 \\
\hline
\end{tabular}


